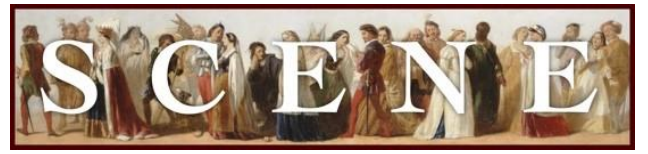

\title{
Lazarus Theatre's All-Female Henry V at The Union Theatre, London
}

by Kevin Quarmby. Written on 2015-06-30. Published in 2017 Issue 1.

For the production: Henry V (2015, Lazarus Theatre Company, England). See production details at the end of the review.

RANDOMLY STAGGERED BY OUR NUMBERED TICKETS, WE ENTER THE BLACK BOX claustrophobia of the Union Theatre Southwark to experience that most militaristic of plays, Henry $V$. The stage and seating immediately foreground the play's novel treatment by Lazarus Theatre Company, and the vision of its director, Ricky Dukes. Two rows of seats surround the central acting space on three sides, the distant fourth obscured by smoke and bright lights. Within this outer raised audience platform, another row of black metal seats delineate the stage like silent military guards. Props, books, documents, strategically situated beneath, punctuate the uniform somberness of this silent, inward-facing barrier.

A long rectangular table, draped with a golden yellow altar cloth and bearing yet more symbols of authority and power, dominates the central cramped acting space. A vellum-bound Bible, a bowl of burning candles, and other cathedral-style flames, flickering and glimmering through the haze, add to the religiosity of the image. In the table's center, a Perspex cube supports a regal fleur-de-lis crown, a powerful signifier that radiates golden shards of light. Barely visible, actors hum in the background like animatronic Gregorian chanters, their vocalized utterings resonating through our bodies. The scene is set.

The dramatic simplicity of the stage's arrangement appears in stark contrast to the complex intellectual journey we will travel. When, with the play's opening Chorus (voiced with astonishing clarity by RJ Seeley), we are advised to take imaginative leaps into the unfolding narrative, we little suspect how successful these leaps will be in the hands of so committed an ensemble. French embassies might dismiss England's new ruler with disdainful sporting gifts. Prelates might plot and conspire to urge their military ambitions. Traitors might be executed with cool offstage malice. Battles fought and won by report and minimal physical contact. The whole play relies on the company's ability to plant these images in our minds. That they do so so 
effectively is evidence of the rationality behind the production's core concept, and its committed execution.

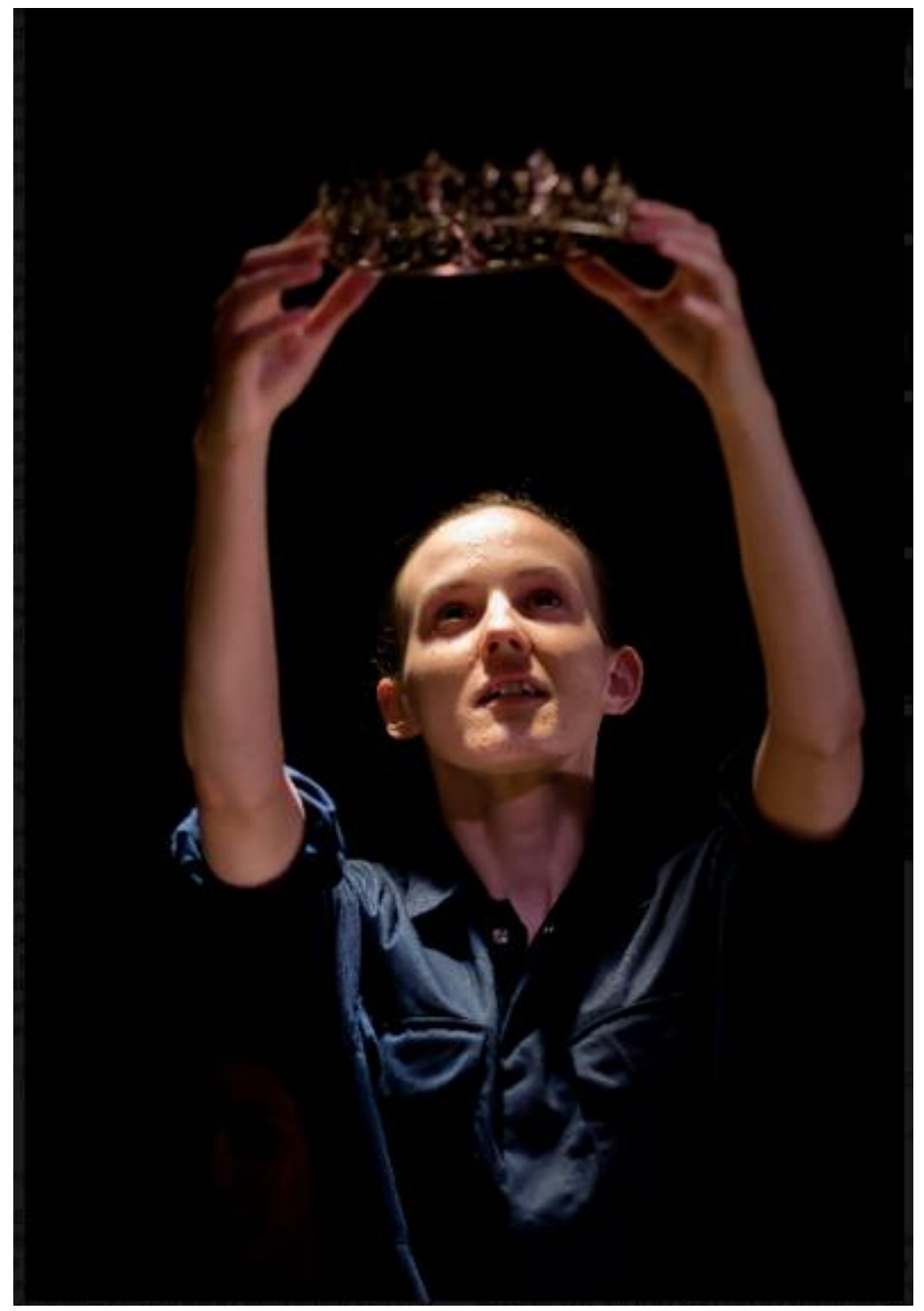

Figure 1: Colette O'Rourke as Henry V. Photograph by Adam Trigg

Fundamental is the decision by Dukes to regender the entire play. Female actors perform all the roles in this fast-paced rendering, which runs at just over two hours including interval. Packed into two hours are an abused English court, a martial campaign in France, and the defeat of the massed French army on the field of Agincourt. To accommodate the swiftness of the narrative, the French are all but expunged from the tale. With only the French emissary to clown with Gallic pride, we might lose the Princess Katherine and her pseudo-comic Frenglish, but we gain in a focused appreciation of the play's sometimes underlying, but mostly overt violence. An allfemale cast might lead some to question the company's commitment to Shakespeare. Do not 
prejudge. Nothing should deter you from experiencing the undeniable strength and vitality of this innovative Henry $V$.

To see Lazarus Theatre Company's Henry V is to dispel any notion of cross-casting gimmickry. Within moments, the gender of the performers becomes insignificant. What remains is a narrative sweep that gains in nuance and focus, voiced afresh by a cast who relish the text rather than concern themselves with "manly" posturing or falsehood. The result? A very real, very disturbing image of nationalistic pride and patriotism. Indeed, the very heritage of patriotic behavior, as the fervent belief in a patris or "fatherland," achieves its heightened significance in this subtly reimagined construct.

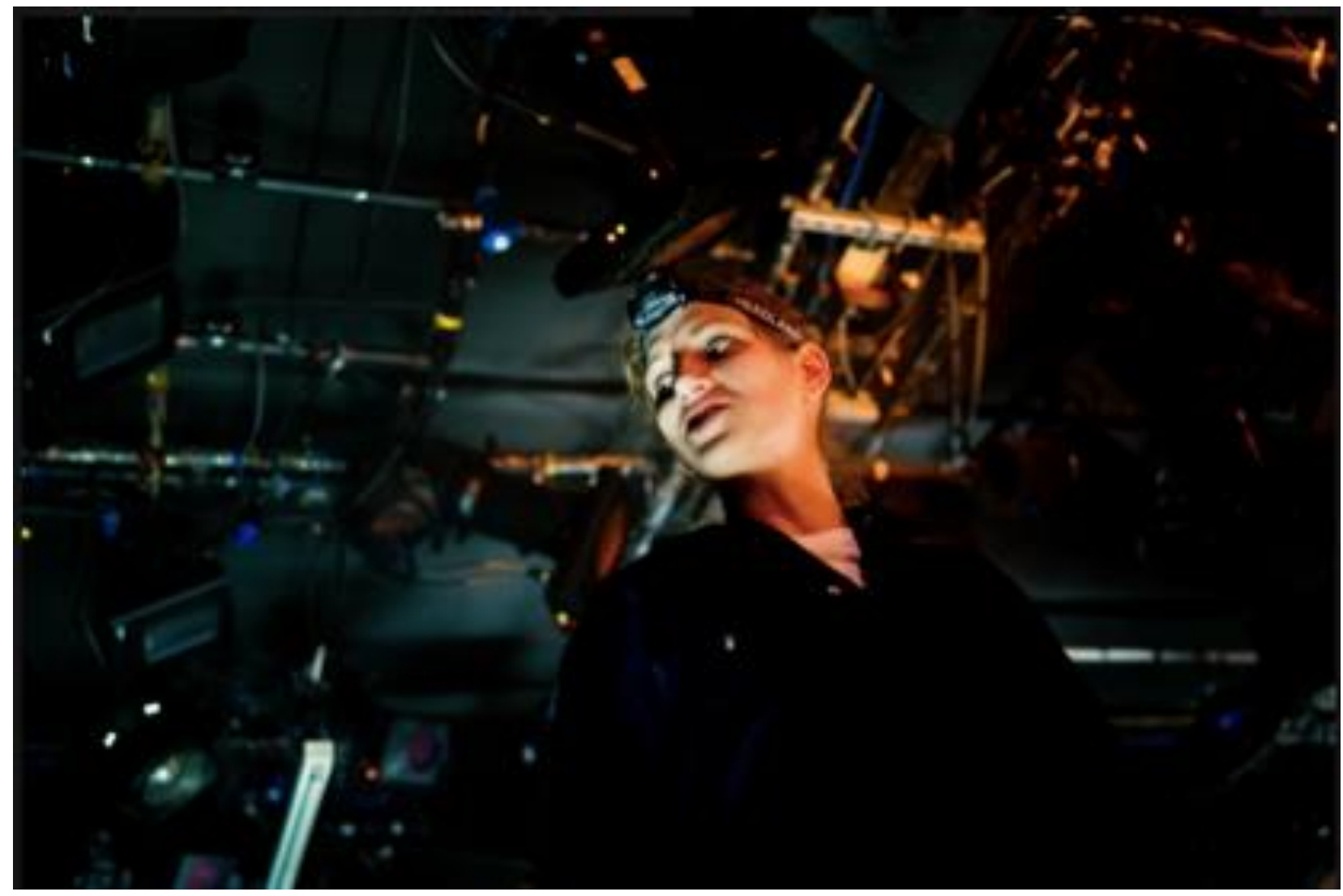

Figure 2: R] Seeley as Fluellen. Photograph by Adam Trigg.

Rather than don false facial hair and strut like unconvincing impersonators, the Lazarus actors choose instead to bring their own personalities and physical traits to their characters. Colette O'Rourke's King Henry becomes, therefore, a malevolent post-adolescent psychopathic menace, at ease with blowing the brains out of conspirators, as ordering the mass execution of French prisoners of war. O'Rourke's malignant delivery of the Siege of Harfleur speech, not shouted but whispered with amplified horridness through a megaphone, is a highlight of the evening. This King Henry is a cold calculating killer. Threat and danger accompany every regal 
step the monarch takes, even when urging his followers' fatal support with, "We few, we happy few, we band of brothers".

The malice of Henry is amplified also by the company's close proximity to the audience, and their effective demand for piercing eye contact with all they address. The close confines of the stage prove likewise effective in the exchanges between Henry's fractious nationally defined troops. Yet again, RJ Seeley shines as the annoyingly comic Welshman, Fluellen. Seeley's relaxed and impeccable delivery transforms a comedy turn into a fascinating dramatic foil for O'Rourke's Henry. As the king's psychosis develops into revengeful decisiveness, so Fluellen's vociferous adulation seems more poignant, innocent, and trusting. We are left asking, how might we react to such jingoistic glorification of war? Are we, like Fluellen, doomed to ovine slaughter because of the cult of celebrity that surrounds our leaders?

What defines us as men? What defines us as women? Must aggression and psychopathic threat always be gendered "male," or do their societal manifestations cross the binary boundaries of male/female behavior to create an asexual malice, as distinctive as it is dangerous? These are questions that the Lazarus Theatre Company's Henry V invites of its audience. It is a production that makes you think. It is a production that will haunt you long after leaving the under-arch darkness of the Union Theatre.

Kevin Quarmby (Editor, Scene) is assistant professor of English at Oxford College of Emory University. His doctorate in Shakespeare and Early Modern Drama was awarded by King's College London following an MA taught jointly at King's and Shakespeare's Globe Theatre. 'Dr Q', as his students call him, has published extensively on Shakespeare in international scholarly journals, with articles in Shakespeare Survey, Shakespeare, and Shakespeare Bulletin. He is editing I Henry VI for Internet Shakespeare Editions, and is the founding Editor of the ISE's performance review journal, Scene. His monograph, The Disguised Ruler in Shakespeare and His Contemporaries (2012; republished by Routledge in paperback 2016), was shortlisted for the Globe Theatre Book Award 2014. Recent Shakespeare in performance criticism includes 'Sexing Up Goneril: Feminism and Fetishization in Contemporary King Lear Performance', in Women Making Shakespeare, ed. McMullan, Orlin, and Mason Vaughan (Bloomsbury, 2013). Quarmby's ongoing concern for social justice reform informs his research interests in the "Shakespeare in Prison" educational model, food, and land justice, and the misappropriation of Shakespeare in the global political arena. An established theater reviewer and professional actor turned scholar, Quarmby is excited to lead Scene on its future ventures, and to explore the scholarly and pedagogical potential of this digital review journal. 


\section{Production Details}

\section{General}

$\begin{array}{ll}\text { Title } & \text { Henry V } \\ \text { Year } & 2015 \\ \text { Theater Company } & \text { Lazarus Theatre Company } \\ \text { Theaters } & \text { Union Theatre (UK) } \\ \text { Start Date } & 2015-06-30 \\ \text { End Date } & 2015-07-18\end{array}$

\section{Cast}

\begin{tabular}{|c|c|}
\hline JAMY (THE INTELLIGENCER) & LOUISE GOODFIELD \\
\hline WESTMORELAND (THE CONCILIATOR) & GRETA GOULD \\
\hline EXETER (THE PROTECTOR) & КЕMI-BO JACOBS \\
\hline BISHOP OF ELY (THE INTERPRETER) & ELLY LOWNEY \\
\hline MACMORRIS (THE OBSERVER) & NUALA McGOWAN \\
\hline King Henry (THE COMMANDER-IN-Chief) & COLETte O'ROURKe \\
\hline PISTOL (THE ADMINISTRATOR) & EMILY OWENS \\
\hline FLUELLEN (THE TACTICIAN) & RJ SEELEY \\
\hline GOWER (THE ENFORCER) & SOPHIE TANZA QUINN \\
\hline ARCHBISHOP OF CANTERBURY (THE DIVINE) & KERRY WILLISON-PARRY \\
\hline
\end{tabular}

\section{Creatives}

\begin{tabular}{|c|c|}
\hline DIRECTOR & RICKY DUKES \\
\hline ASSOCIATE DIRECTOR & GAVIN HARRINGTON-ODEDRA \\
\hline ASSISTANT DIRECTOR & Josh Hinds \\
\hline DRAMATURGE & SARA REIMERS \\
\hline COSTume Designer & RACHEL DINGLE \\
\hline Lighting Designer & STUART GLOVER \\
\hline SOUNd DESIGNER & NEIL MCKEOWN \\
\hline Stage MANAGER & LORRELL RAWLINS \\
\hline PRODUCTION MANAGER & INA BERGGREN \\
\hline PRODUCTION GRAPHIC DESIGNER & WiLL BEESTON \\
\hline COMPANY PHOTOGRAPHER & ADAM TRIGG \\
\hline
\end{tabular}

